\title{
Krzysztof Cień
}

Uniwersytet Marii Curie-Skłodowskiej w Lublinie

krzysztof.cien.umcs@gmail.com

\section{Problematyka zakresu podmiotowego opodatkowania podatkiem od towarów i usług wynajęcia nieruchomości stanowiącej współwłasność}

\author{
The Problem of the Subjective Scope of the Taxation with Tax \\ on Goods and Services of Leasing the Property Constituting \\ the Co-ownership
}

\section{STRESZCZENIE}

Niniejszy artykuł dotyczy wpływu niektórych zdarzeń cywilnoprawnych, odnoszących się do stosunku między współwłaścicielami, na zakres podmiotowy opodatkowania podatkiem od towarów i usług świadczenia usługi najmu nieruchomości stanowiącej współwłasność. Należy zauważyć, że liczne i rozbieżne orzecznictwo świadczy o wadze tego problemu. W opracowaniu przedstawiono niektóre zdarzenia cywilnoprawne dotyczące współwłasności nieruchomości, takie jak podział quoad usum nieruchomości, ustanowienie zarządcy nieruchomości będącego współwłaścicielem i ustanowienie zarządcy spoza grona współwłaścicieli nieruchomości. Następnie dokonano analizy wpływu tych zdarzeń na zakres podmiotowy opodatkowania usługi najmu nieruchomości wspólnej. Trzeba podkreślić, że omawiane kwestie dotyczą również szerszego zagadnienia, jakim jest problematyka związków prawa podatkowego z prawem cywilnym.

Słowa kluczowe: nieruchomość; współwłasność; podział quoad usum; zarządca; najem; podatek od towarów i usług; usługa; podatnik

\section{WPROWADZENIE}

Wynajmowanie nieruchomości wspólnej przez współwłaścicieli jest zjawiskiem dość powszechnym. $Z$ tego tytułu współwłaściciele nieruchomości pobierają czynsz najmu, który stanowi pożytek z rzeczy stanowiącej przedmiot współ- 
własności. W świetle art. 207 Kodeksu cywilnego ${ }^{1}$, który ma charakter ius dispositivi, pożytki i inne przychody z rzeczy wspólnej przypadają współwłaścicielom w stosunku do wielkości udziałów; w takim samym stosunku współwłaściciele ponoszą wydatki i ciężary związane z rzeczą wspólnąa ${ }^{2}$ Do owych ciężarów zalicza się m.in. podatki, w tym podatek od towarów i usług ${ }^{3}$, jeżeli współwłaściciele nieruchomości są podatnikami w rozumieniu przepisów o podatku od towarów i usług. Na gruncie ustawy normującej ten podatek świadczą oni bowiem usługę najmu. Co do zasady każdy ze współwłaścicieli wynajmowanej nieruchomości, jeżeli wykonuje samodzielnie działalność gospodarczą, o której mowa w art. 15 ust. 2 ustawy o podatku od towarów i usług, jest czynnym podatnikiem tego podatku. Jednakże na skutek niektórych zdarzeń cywilnoprawnych ${ }^{4}$, odnoszących się do stosunku między współwłaścicielami, krąg podatników czynnych podatku od towarów i usług może ulec zmianie. Trzeba zaznaczyć, że nie każde zdarzenie cywilnoprawne na gruncie współwłasności skutkuje zwiększeniem bądź zmniejszeniem liczby podatników podatku od towarów i usług z tytułu świadczenia usługi najmu nieruchomości. Analiza orzecznictwa pokazuje, że stwierdzenie wpływu lub braku wpływu wspomnianych zdarzeń na zakres podmiotowy opodatkowania podatkiem od towarów i usług wynajęcia nieruchomości wspólnej przez współwłaścicieli stwarza wiele wątpliwości zarówno dla organów podatkowych, jak i sądownictwa administracyjnego.

Celem niniejszego opracowania jest ukazanie, w jaki sposób wybrane zdarzenia cywilnoprawne na gruncie współwłasności wynajmowanej nieruchomości wpływają na zakres podmiotowy opodatkowania usługi najmu podatkiem od towarów i usług. Liczne i rozbieżne orzecznictwo w tej kwestii świadczy o wadze tego problemu. Ponadto zagadnienie to, poza nielicznymi wyjątkami ${ }^{5}$, nie było obiektem szerszego zainteresowania w literaturze przedmiotu.

Należy postawić tezę, że prawidłowe opodatkowanie podatkiem od towarów i usług usługi najmu nieruchomości wspólnej jest w dużej mierze uzależnione od prawidłowego ustalenia podmiotów będących w danym stanie faktycznym czynnymi podatnikami tego podatku. Aby tak się stało, organy stosujące prawo powinny ustalić stan faktyczny z należytym zastosowaniem przepisów Kodeksu cywilnego dotyczących współwłasności, w szczególności w zgodzie z istotą tej instytucji. Ustawa o podatku od towarów i usług nie zawiera bowiem własnych norm

\footnotetext{
${ }^{1}$ Ustawa z dnia 23 kwietnia 1964 r. - Kodeks cywilny (t.j. Dz.U. z 2016 r., poz. 380 ze zm.).

${ }^{2}$ Por. A. Cisek, K. Górska, [w:] Kodeks cywilny. Komentarz, red. E. Gniewek, P. Machnikowski, Warszawa 2013, s. 360.

${ }^{3}$ Ustawa z dnia 11 marca 2004 r. o podatku od towarów i usług (t.j. Dz.U. z 2017 r., poz. 1221 ze zm.).

${ }^{4}$ Zob. szerzej: A. Wolter, Prawo cywilne. Zarys części ogólnej, Warszawa 1979, s. 105 i n.

${ }^{5} \mathrm{Na}$ temat sporu między współwłaścicielami wynajmującymi nieruchomość wspólną i jego wpływu na podatkowy stan faktyczny zob. S. Brzeszczyńska, Wynajęcie nieruchomości wspólnej przez skłóconych wspótwłaścicieli, „Nieruchomości” 2015, nr 9, s. 21 i n.
} 
definiujących podstawowe pojęcia i konstrukcje charakterystyczne dla współwłasności rzeczy ${ }^{6}$.

Aby przedstawić niniejszy problem, należy przede wszystkim dokonać analizy dogmatycznej obowiązujących źródeł prawa cywilnego i podatkowego, a także judykatury w tej kwestii. W omawianej materii orzeczenia nie są jednolite i zawierają istotne rozbieżności. Ich wnikliwe zbadanie umożliwi poznanie, jakie zasady dotyczące współwłasności są pomijane przez organy stosujące prawo, a które mogą mieć wpływ na należyte określenie kręgu podatników podatku od towarów i usług w przypadku wynajęcia nieruchomości stanowiącej współwłasność.

Prawidłowe przedstawienie omawianego zagadnienia jest możliwe tylko dzięki wyszczególnieniu wspomnianych zdarzeń cywilnoprawnych mających wpływ bądź nie na zakres podmiotowy opodatkowania wynajęcia nieruchomości wspólnej. Należy zatem wskazać i przedstawić następujące zdarzenia: podział quoad usum nieruchomości i jego znaczenie dla zakresu podmiotowego opodatkowania wynajęcia nieruchomości wspólnej, ustanowienie zarządcy nieruchomości będącego współwłaścicielem i znaczenie tego zdarzenia dla owego zakresu oraz ustanowienie zarządcy niebędącego współwłaścicielem i ustalenie podatkowych skutków dla omawianej problematyki. Rozważania muszą jednak być poprzedzone uwagami dotyczącymi umowy najmu na gruncie podatku od towarów i usług.

\section{UMOWA NAJMU NA GRUNCIE USTAWY O PODATKU OD TOWARÓW I USŁUG}

Czynność cywilnoprawna, jaką jest zawarcie umowy najmu, rodzi skutki prawne nie tylko na gruncie prawa cywilnego, ale również na płaszczyźnie prawnopodatkowej. Omawiana problematyka będzie jednak dotyczyć wyłącznie skutków prawnych wynajmowania nieruchomości wspólnej na gruncie podatku od towarów i usług.

Zgodnie $\mathrm{z}$ art. 5 ust. 1 pkt 1 ustawy o podatku od towarów i usług opodatkowaniu podatkiem od towarów i usług podlega odpłatna dostawa towarów i odpłatne świadczenie usług na terytorium kraju. Natomiast przez pojęcie świadczenia usług, w myśl art. 8 ust. 1 ustawy o podatku od towarów i usług, należy rozumieć każde świadczenie na rzecz osoby fizycznej, osoby prawnej lub jednostki organizacyjnej niemającej osobowości prawnej, które nie stanowi dostawy towarów w rozumieniu art. 7 tej ustawy, czyli przeniesienia prawa do rozporządzania towarami jak właściciel ${ }^{7}$.

\footnotetext{
${ }^{6}$ Zob. szerzej: A. Hanusz, Zasada autonomii woli stron stosunków cywilnoprawnych $w$ świetle prawa podatkowego, „Państwo i Prawo” 1998, z. 12, s. 39.

${ }^{7}$ Zob. więcej: T. Michalik, VAT. Komentarz, Warszawa 2015, s. 115 i n.
} 
Należy też zwrócić uwagę na treść art. 15 ust. 1 ustawy o podatku od towarów i usług, który stanowi, że podatnikami są osoby prawne, jednostki organizacyjne nieposiadające osobowości prawnej oraz osoby fizyczne wykonujące samodzielnie działalność gospodarczą, bez względu na cel lub rezultat takiej działalności. W tym miejscu wypada zasygnalizować, że niniejsze opracowanie i uwagi w nim zawarte odnoszą się tylko do podmiotów będących podatnikami w rozumieniu wyżej wymienionego przepisu.

$\mathrm{Z}$ kolei za działalność gospodarczą w rozumieniu ustawy o podatku od towarów i usług należy rozumieć, zgodnie z art. 15 ust. 2 tej ustawy, wszelką działalność producentów, handlowców lub usługodawców, w tym podmiotów pozyskujących zasoby naturalne oraz rolników, a także działalność osób wykonujących wolne zawody. Działalność gospodarcza, w rozumieniu tego przepisu, obejmuje w szczególności czynności polegające na wykorzystywaniu towarów lub wartości niematerialnych i prawnych w sposób ciągły dla celów zarobkowych. Mając na uwadze powyższe przepisy, trzeba stwierdzić, iż co do zasady najem na gruncie podatku od towarów i usług stanowi usługę nim opodatkowaną ${ }^{8}$.

Obowiązek podatkowy $\mathrm{w}$ przypadku świadczenia usługi najmu powstaje z chwilą wystawienia faktury, przy czym faktura powinna być wystawiona nie później niż z upływem terminu płatności ${ }^{9}$. Gdy podatnik nie wystawił faktury lub wystawił ją z opóźnieniem, obowiązek podatkowy powstaje z chwilą upływu terminów wystawienia faktury, a w przypadku gdy nie określono takiego terminu - z chwilą upływu terminu płatności.

Stosownie do art. 29a ustawy o podatku od towarów i usług podstawą opodatkowania jest wszystko, co stanowi zapłatę, którą dokonujący dostawy lub usługodawca ma otrzymać z tytułu sprzedaży od nabywcy, usługobiorcy lub osoby trzeciej, włącznie z otrzymanymi dotacjami, subwencjami i innymi dopłatami o podobnym charakterze, mającymi bezpośredni wpływ na cenę towarów dostarczanych lub usług świadczonych przez podatnika. W przypadku najmu nieruchomości podstawę opodatkowania co do zasady będzie stanowił czynsz najmu ${ }^{10}$.

\footnotetext{
${ }^{8}$ Więcej na temat problemu, czy najem mieszkania prywatnego stanowi działalność gospodarczą, zob. Ł. Matusiakiewicz, Najem nieruchomości a VAT-kontrowersyjne problemy w świetle najnowszych interpretacji organów podatkowych, „Nieruchomości” 2012, nr 4, s. 28 i n. Por. również uwagi dotyczące zwolnienia od podatku od towarów i usług najmu nieruchomości mieszkalnych: T. Krywan, VAT. Komentarz 2013, Wrocław 2013, s. 550-551.

${ }^{9}$ Zob. art. 19a ust. 5 pkt 4 lit. b tiret trzeci ustawy o podatku od towarów i usług.

${ }^{10}$ Zagadnienie wliczania do podstawy opodatkowania kwot z tytułu dostawy mediów wzbudza wiele wątpliwości. Zob. wyroki NSA: z dnia 25 sierpnia 2015 r., I FSK 1672/13, Legalis nr 1361710; z dnia 1 października 2015 r., I FSK 1004/13, Legalis nr 1362239.
} 


\section{PODZIAŁ QUOAD USUM NIERUCHOMOŚCI}

W myśl art. 206 Kodeksu cywilnego każdy ze współwłaścicieli jest uprawniony do współposiadania rzeczy wspólnej oraz do korzystania z niej w takim zakresie, jaki daje się pogodzić ze współposiadaniem i korzystaniem z rzeczy przez pozostałych współwłaścicieli. Przepis ten ma jednak charakter dyspozytywny, co oznacza, że współwłaściciele mogą inaczej ukształtować sposób korzystania z rzeczy wspólnej ${ }^{11}$. W szczególności mogą oni zawrzeć umowę o podział quoad usum ${ }^{12}$. Skutek w postaci podziału quoad usum rzeczy wspólnej może wywołać także orzeczenie sądu, które uwzględnia roszczenie o dopuszczenie do współposiadania i korzystania z rzeczy wspólnej. Należy podkreślić, że bez względu na sposób dokonanego podziału, istota i cechy charakterystyczne podziału rzeczy wspólnej do wyłącznego korzystania są takie same zarówno przy podziale sądowym, jak i umownym ${ }^{13}$. Omawiany podział quoad usum nie pozostaje bez wpływu również na zakres podmiotowy opodatkowania podatkiem od towarów i usług wynajęcia nieruchomości wspólnej.

Podział rzeczy quoad usum określa formę współposiadania i korzystania z rzeczy wspólnej. W systemie prawa nie znajduje się żadna norma definiująca to pojęcie, jednakże istotę podziału rzeczy do wyłącznego korzystania wyjaśnia orzecznictwo. W uchwale z dnia 8 sierpnia 1980 r. Sąd Najwyższy stwierdził, że podział quoad usum nieruchomości:

[...] polega on na tym, że każdy ze współwłaścicieli otrzymuje do wyłącznego użytku fizycznego wydzieloną część nieruchomości. Każdy więc, jeżeli w umowie nie określono inaczej, oddzielnie używa swojej części i oddzielnie czerpie z niej pożytki i równocześnie w takim też zakresie każdy ze współwłaścicieli, mając fizycznie wydzieloną część, odpowiadającą wielkości jego udziału, ponosi wszystkie związane z eksploatacją części wydatki ${ }^{14}$.

Po podziale quoad usum współwłaściciele dalej pozostają współposiadaczami samoistnymi rzeczy wspólnej, lecz uzyskują w ten sposób posiadanie zależne poszczególnych części nieruchomości ${ }^{15}$. W wyniku dokonanego podziału korzy-

${ }^{11}$ Por. J. Ignatowicz, [w:] Kodeks cywilny. Komentarz, red. J. Ignatowicz, J. Pietrzykowski, t. 1, Warszawa 1972, s. $521 \mathrm{i}$.

${ }^{12}$ Zgodnie $\mathrm{z}$ jedną z podstawowych zasad prawa cywilnego, jaką jest zasada autonomii woli stron, każda osoba może własną mocą kształtować swoje stosunki prawne, ale oczywiście w granicach prawa. Współwłaściciele rzeczy wspólnej mogą zatem ukształtować swój stosunek prawny w zakresie korzystania z niej swobodnie, jednakże w granicach określonych przepisami prawa. Zob. A. Wolter, op. cit., s. 15. W odniesieniu do prawa podatkowego por. A. Hanusz, op. cit., s. 36 i n.

${ }_{13}$ Zob. K. Czerwińska-Koral, Podział quoad usum nieruchomości rolnej, Warszawa 2015, s. 156 .

${ }^{14}$ Zob. uchwała SN z dnia 8 stycznia 1980 r., III CZP 80/79, Legalis nr 21842.

${ }^{15}$ Więcej na temat posiadania zob. A. Kunicki, [w:] System Prawa Cywilnego, t. 2: Prawo własności i inne prawa rzeczowe, red. W. Czachórski, Warszawa 1977, s. 825 i n. 
stają z określonych części nieruchomości na zasadzie wyłączności. Podział rzeczy quoad usum jest bowiem wewnętrznym zorganizowaniem sposobu korzystania z rzeczy wspólnej ${ }^{16}$. W razie podziału nieruchomości do korzystania wydzielone części nie muszą odpowiadać wielkości udziałów współwłaścicieli ${ }^{17}$. Ponadto podział nieruchomości quoad usum nie przyznaje współwłaścicielom żadnych nowych uprawnień w stosunku do części rzeczy, którą otrzymali do wyłącznego korzystania. Przysługują im wyłącznie te uprawnienia, które wynikają z instytucji współwłasności. Wszelkie dokonywane czynności powinny być rozpatrywane pod kątem tego, czy mieszczą się w granicach zwykłego zarządu rzeczą czy też są czynnościami przekraczającymi zwykły zarząd, do których potrzebna jest zgoda pozostałych współwłaścicieli ${ }^{18}$. Sąd Najwyższy w wyroku z dnia 10 lutego $2004 \mathrm{r}$. wskazał, że każdy ze współwłaścicieli może samodzielnie dokonywać czynności w stosunku do tej części rzeczy wspólnej, z której samodzielnie korzysta ${ }^{19}$. Zatem każdy ze współwłaścicieli może wynająć część nieruchomości, którą otrzymał do wyłącznego korzystania.

Ponadto w przypadku podziału nieruchomości quoad usum $\mathrm{w}$ ten sposób, że każdy ze współwłaścicieli korzysta na zasadzie wyłączności z określonej części nieruchomości, nie ma zastosowania zasada podziału pożytków i przychodów według wielkości udziałów ${ }^{20}$. W wyroku z dnia 15 czerwca 1993 r. Sąd Apelacyjny w Gdańsku stwierdził, że ,jeżeli współwłaściciele określą prawo do korzystania z wydzielonej części rzeczy przez współwłaściciela w sposób wyłączny (quoad usum), istnieje domniemanie, że temu współwłaścicielowi przypadają pożytki i dochody z rzeczy również w sposób niepodzielny"21. Przyjąć zatem należy, że współwłaściciel, który korzysta wyłącznie z określonej części rzeczy, może zarówno dokonywać nakładów na rzecz, jak i czerpać z niej korzyści z wyłączeniem pozostałych współwłaścicieli.

Z kolei uzgodnienie między współwłaścicielami, że każdy z nich będzie pobierał czynsz najmu od innego lokalu, nie stanowi podziału quoad usum, gdyż jest to tylko określenie sposobu podziału między współwłaścicieli dochodu ze wspólnej nieruchomości i nie wywiera skutku w zakresie posiadania ${ }^{22}$.

16 Tak: E. Gniewek, [w:] System Prawa Prywatnego, t. 3: Prawo rzeczowe, red. E. Gniewek, Warszawa 2013, s. 700.

${ }^{17}$ Por. M. Durzyńska, Podział nieruchomości, Warszawa 2011, s. 245.

${ }^{18}$ Zob. K. Czerwińska-Koral, op. cit., s. 152.

${ }^{19}$ Tak: wyrok SN z dnia 10 lutego 2004 r., IV CK 17/03, Legalis nr 68861.

${ }^{20}$ Por. S. Rudnicki, G. Rudnicki, J. Rudnicka, [w:] Kodeks cywilny. Komentarz, Księga II: Wtasność i inne prawa rzeczowe, red. J. Gudowski, Warszawa 2013, s. 358; uchwała SN z dnia 8 stycznia 1980 r., III CZP 80/79, Legalis nr 21842.

${ }^{21}$ Tak: wyrok SA w Gdańsku z dnia 15 czerwca 1993 r., I ACr 400/93, Legalis nr 46319.

${ }^{22}$ Zob. wyrok SN z dnia 29 grudnia 1967 r., III CRN 306/67, OSNCP 1968, poz. 215. 


\section{WPŁYW PODZIAŁU QUOAD USUM NA ZAKRES PODMIOTOWY OPODATKOWANIA USŁUGI NAJMU NIERUCHOMOŚCI WSPÓLNEJ}

Stosownie do powyższych uwag trzeba stwierdzić, że tak współwłaściciele, jak i sąd mogą dokonać podziału nieruchomości do korzystania. Mając na względzie ten fakt, należy odnieść go do zakresu podmiotowego opodatkowania podatkiem od towarów i usług usługi najmu nieruchomości wspólnej, ponieważ zdarzenie to wpływa na ów zakres. Skutki podziału quoad usum na gruncie prawa podatkowego są bowiem zagadnieniem budzącym wątpliwości dla podatników ${ }^{23}$.

Współwłaściciel, który otrzymał część nieruchomości do wyłącznego korzystania, może ją wynająć. W ten sposób będzie on na zasadzie wyłączności pobierał korzyści, jakie płyną z umowy najmu, a więc czynsz najmu. Taka sytuacja będzie również podatkowym stanem faktycznym, ponieważ na gruncie ustawy o podatku od towarów i usług będzie on świadczył usługę najmu. Świadczenie należne mu z tytułu świadczonej usługi będzie stanowiło przedmiot opodatkowania podatkiem od towarów i usług. Współwłaściciel ten będzie jednak jedynym podatnikiem czynnym podatku od towarów i usług, gdyż tylko on czerpie korzyści na zasadzie wyłączności. Wynika to z treści przepisu art. $659 \S 1$ Kodeksu cywilnego. W myśl wyżej przywołanego przepisu tylko ten, kto zobowiązuje się do oddania rzeczy do używania (wynajmujący), uzyskuje w zamian czynsz najmu, który zobowiązuje się płacić najemca. Ustalenie, że będzie on jedynym podatnikiem, wynika ze stwierdzenia, że tylko on wynajmuje przedmiotową nieruchomość i w konsekwencji tego tylko on jest beneficjentem umowy najmu. $\mathrm{Z}$ całą pewnością nie będą czynnymi podatnikami podatku od towarów i usług pozostali współwłaściciele, gdyż nie są oni stroną umowy najmu i w konsekwencji nie czerpią z niej korzyści. Wynika to z faktu, że wynajmowana jest tylko część nieruchomości. Nie należy więc przyjmować, że podatnikami są wszyscy współwłaściciele, bo umowa odnosi się do nieruchomości stanowiącej współwłasność. Istotą tego zagadnienia jest to, że umowa najmu ma za przedmiot oddanie do używania części nieruchomości, z której współwłaściciel korzysta w sposób wyłączny.

W praktyce może mieć miejsce też przypadek, w którym w wyniku podziału quoad usum jeden ze współwłaścicieli uzyskuje prawo do rozporządzania całą nieruchomością i w ramach przysługujących mu uprawnień wynajmuje całą nieruchomość, a pozostali rezygnują z pożytków, jakie mogą osiągnąć z rzeczy wspólnej. Nawet w takiej sytuacji tylko on będzie podatnikiem czynnym podatku od towarów i usług, mimo że umowa najmu odnosi się do całej nieruchomości sta-

${ }^{23}$ Por. przykładowo interpretację indywidualną Dyrektora Izby Skarbowej w Warszawie z dnia 30 marca 2009 r., IPPP1/443-91/09-4/AW. 
nowiącej współwłasność. Samo wynajęcie nieruchomości wspólnej przez jednego współwłaściciela nie czyni pozostałych współwłaścicieli czynnymi podatnikami tego podatku z tytułu świadczenia usługi najmu nieruchomości ${ }^{24}$.

Pozostali współwłaściciele mogą oczywiście wynająć swoje części nieruchomości i w ten sposób stać się czynnymi podatnikami podatku od towarów i usług. Opodatkowaniu będzie podlegała wówczas należność z tytułu czynszu najmu, jaką otrzymają na zasadzie wyłączności.

Podział quoad usum nieruchomości wspólnej będzie skutkował zatem sytuacją, w której nie wszyscy współwłaściciele są podatnikami podatku od towarów i usług, ale tylko ten współwłaściciel, który postanowił wynająć część nieruchomości wspólnej wykorzystywanej przez niego w sposób wyłączny bądź ten, który wynajmuje całą nieruchomość, a pozostali współwłaściciele zrezygnowali z pożytków, jakie przynosi rzecz wspólna.

\section{ZARZĄD RZECZĄ BĘDĄCĄ PRZEDMIOTEM WSPÓŁWŁASNOŚCI}

Analizując zagadnienie wpływu zdarzeń cywilnoprawnych odnoszących się do współwłasności na zakres podmiotowy opodatkowania podatkiem od towarów i usług wynajęcia nieruchomości wspólnej, należy zwrócić uwagę na kwestię zarządu rzeczą wspólną, a konkretnie na zagadnienie ustanowienia zarządcy. Osoba zarządcy oraz sposób jego ustanowienia mają znaczenie dla prawidłowego ustalenia zakresu podmiotowego opodatkowania tym podatkiem wynajęcia nieruchomości stanowiącej własność współwłaścicieli. Zarządca może być ustanowiony na mocy umowy zawartej przez współwłaścicieli bądź na skutek powołania przez sąd.

W związku z tym, że przepisy Kodeksu cywilnego regulujące zarząd rzeczą wspólną mają charakter dyspozytywny, współwłaściciele mogą w drodze umowy ustalić inny sposób jej zarządu. W szczególności mogą postanowić, że zarząd rzeczą wspólną będzie sprawował w imieniu wszystkich jeden ze współwłaścicieli albo osoba trzecia. W umowie powierzającej wykonywanie zarządu można również określić rodzaj czynności prawnych lub faktycznych, do których wykonania będzie potrzebna zgoda wszystkich albo większości współwłaścicieli. Należy jednak zauważyć, iż umowa powierzająca wykonywanie zarządu zarządcy wyłącza uprawnienia pozostałych współwłaścicieli do sprawowania zarządu rze-

${ }^{24}$ Tak: S. Brzeszczyńska, op. cit., s. 24. Natomiast na temat podziału quoad usum na gruncie podatku od spadków i darowizn zob. P. Szczęśniak, Glosa do wyroku Naczelnego Sądu Administracyjnego z dnia 5 lutego 2015 r., sygn. akt II FSK 146/13 (dot. nieskuteczności umowy o podziat quoad usum na gruncie ustawy o podatku od spadków i darowizn), „Zeszyty Naukowe Sądownictwa Administracyjnego" 2015, z. 6, s. 147 i n. 
czą wspólnąą 2 Z całą pewnością do praw i obowiązków zarządcy należy dokonywanie czynności prawnych, takich jak m.in. zawieranie umów, czynności faktycznych, a także reprezentacja współwłaścicieli. Do jego obowiązków będzie poza tym należało przekazywanie przychodów i pożytków, jakie przynosi rzecz wspólna, stosownie do postanowień umowy o powierzeniu zarządu, a w przypadku ich braku - zgodnie z regulacją art. 207 Kodeksu cywilnego.

Ponadto, zgodnie z art. 203 Kodeksu cywilnego, w sytuacji gdy nie można uzyskać zgody większości współwłaścicieli w istotnych sprawach dotyczących zwykłego zarządu albo jeżeli większość współwłaścicieli narusza zasady prawidłowego zarządu lub krzywdzi mniejszość, każdy ze współwłaścicieli może wystąpić do sądu o wyznaczenie zarządcy. Na skutek wydanego orzeczenia ustanawiany jest zarząd sądowy, który stanowi głęboko posuniętą ingerencję w sposób wykonywania zarządu rzeczą wspólną. Jednakże jest on skuteczniejszy w praktyce - w konkretnym stosunku prawnym - od ustawowego reżimu zarządu ${ }^{26}$. Zastosowanie do niego znajdują przepisy Kodeksu postępowania cywilnego ${ }^{27}$ regulujące zarząd związany ze współwłasnością i użytkowaniem ${ }^{28}$ oraz - z mocy odesłania art. 615 Kodeksu postępowania cywilnego - przepisy dotyczące zarządu w toku egzekucji z nieruchomości zawarte w art. 931-941 tej ustawy. Od momentu uprawomocnienia się postanowienia o ustanowieniu zarządcy nabywa on w granicach określonych przez ustawodawcę uprawnienia do wykonywania zarządu, a tracą je współwłaściciele ${ }^{29}$. Jako zarządcę rzeczy wspólnej sąd może ustanowić jednego ze współwłaścicieli albo osobę trzecią. Co do zasady może on samodzielnie dokonywać czynności zwykłego zarządu, zaś czynności przekraczające zakres zwykłego zarządu może dokonać tylko za zgodą współwłaścicieli. W przypadku braku takiej zgody, stosownie do art. $935 \S 3$ Kodeksu postępowania cywilnego, czynność przekraczająca zwykły zarząd może być dokonana tylko i wyłącznie za zgodą sądu. Należy tu zwrócić uwagę na fakt, iż zarządca powinien wykonywać czynności niezbędne do prawidłowego gospodarowania rzeczą wspólną. Zgodnie z art. 935 § 1 Kodeksu postępowania cywilnego ma on prawo pobierać na rzecz współwłaścicieli pożytki z rzeczy, spieniężać je w granicach zwykłego zarządu, a także prowadzić sprawy, które przy wykonywaniu zarządu okażą się potrzebne ${ }^{30}$. Wyraźnego podkreślenia wymaga również przeważające w literaturze przedmiotu stanowisko głoszące, że zarządca wyzna-

${ }^{25}$ Uprawnienia określone w art. 199-202 Kodeksu cywilnego. Zob. S. Rudnicki, G. Rudnicki, J. Rudnicka, op. cit., s. 336.

${ }^{26}$ Tak: E. Gniewek, op. cit., s. 692.

${ }^{27}$ Ustawa z dnia 17 listopada 1964 r. - Kodeks postępowania cywilnego (t.j. Dz.U. z 2016 r., poz. 1822 ze zm.).

${ }^{28}$ Zob. art. 611-616 Kodeksu postępowania cywilnego.

${ }^{29}$ Zob. J. Ignatowicz, op. cit., s. 519.

${ }^{30}$ Por. orzeczenie SN z dnia 13 kwietnia 1966 r., II CR 24/66, „Państwo i Prawo” 1968, z. 2, s. 330 . 
czony przez sąd nie jest przedstawicielem współwłaścicieli, lecz działa we własnym imieniu ${ }^{31}$.

W odniesieniu do zarządu rzeczą wspólną należy ponadto wskazać na regulację art. 205 Kodeksu cywilnego, która odnosi się zarówno do zarządcy sądowego, jak i zarządcy ustanowionego na mocy umowy współwłaścicieli. Zgodnie z jej treścią współwłaściciel sprawujący zarząd rzeczą wspólną może żądać od pozostałych współwłaścicieli wynagrodzenia odpowiadającego uzasadnionemu nakładowi jego pracy. W przypadku zarządcy sądowego o wysokości jego wynagrodzenia rozstrzyga sąd, natomiast wynagrodzenie zarządcy ustanowionego na podstawie umowy określają jej strony.

\section{USTANOWIENIE ZARZĄDCY BĘDĄCEGO WSPÓE WŁAŚCICIELEM A ZAKRES PODMIOTOWY OPODATKOWANIA}

Jak już wcześniej wspomniano, zarządcą ustanowionym na mocy umowy współwłaścicieli albo zarządcą sądowym może być współwłaściciel. Mając na względzie ten fakt, należy odnieść go do zakresu podmiotowego opodatkowania podatkiem od towarów i usług wynajęcia nieruchomości wspólnej przez współwłaścicieli, którzy są podatnikami w rozumieniu art. 15 ust. 1 ustawy o podatku od towarów i usług. Ustanowienie zarządcy będącego współwłaścicielem nieruchomości nie wpływa bowiem na krąg podatników z tytułu wynajęcia nieruchomości wspólnej, czego niestety zarówno organy podatkowe, jak i sądownictwo administracyjne niekiedy nie zauważają.

Gdy zostanie zawarta umowa najmu, najemca - zgodnie z art. 669 Kodeksu cywilnego - obowiązany jest płacić czynsz w terminie umówionym. W przypadku ustanowienia zarządcy najemca przekazuje cały czynsz zarządcy, który następnie, stosownie do art. 207 tej ustawy bądź uzgodnień współwłaścicieli co do podziału pożytków z rzeczy wspólnej, rozdziela go między współwłaścicieli. Przypadająca na współwłaściciela część czynszu jest bowiem zapłatą za świadczoną usługę najmu. W związku z tym każdy ze współwłaścicieli powinien, zgodnie $\mathrm{z}$ art. 106b ustawy o podatku od towarów i usług, wystawić fakturę jako świadczący usługę. Do podstawy opodatkowania powinno wliczać się wyłącznie to, co jest należne każdemu współwłaścicielowi, czyli czynsz najmu jako pożytek obliczony stosownie do udziału bądź uzgodnień między współwłaścicielami co do podziału pożytków ${ }^{32}$. W takiej sytuacji podatnikiem czynnym podatku od to-

${ }^{31}$ Tak: J. Ignatowicz, op. cit., s. 519; J. Winiarz, [w:] Kodeks cywilny z komentarzem, red. J. Winiarz, t. 1, Warszawa 1989, s. 179; E. Skowrońska-Bocian, [w:] Kodeks cywilny. Komentarz, red. K. Pietrzykowski, t. 1, Warszawa 2011, s. 646. Por. też: orzeczenie SN z dnia 26 kwietnia 1966 r., I CR 712/63, OSN 1966, poz. 221.

${ }^{32}$ Zob. wyrok NSA z dnia 13 czerwca 2014 r., I FSK 1066/13, Legalis nr 1043110. 
warów i usług z tytułu usługi najmu jest każdy ze współwłaścicieli, w tym zarządca, ponieważ każdemu z nich przypada zapłata z tego tytułu. Fakt, że jeden ze współwłaścicieli jest współwłaścicielem administrującym (zarządcą) w ramach stosunku najmu nie oznacza bowiem, że przez to drugi ze współwłaścicieli traci przymiot podatnika tego podatku w związku z wynajmem nieruchomości wspólnej ${ }^{33}$. Dokonywania przez zarządcę rozliczeń ze współwłaścicielami nie należy traktować tylko jako realizowanie uprawnień współwłaścicieli określonych w prawie cywilnym, ale również jako przekazywanie korzyści za świadczoną usługę najmu ${ }^{34}$. Uznanie zarządcy za jedynego podatnika w przypadku wynajęcia nieruchomości wspólnej przez współwłaścicieli oznaczałoby oderwanie obowiązku podatkowego od podmiotów dokonujących czynności podlegających opodatkowaniu. Nie ulega też wątpliwości, że beneficjentami takiej umowy najmu są wszyscy współwłaściciele, a nie tylko zarządca. Zarządca jest jedynie „inkasentem" należności za wynajem, przysługującej od najemcy wszystkim współwłaścicielom odpowiednio do posiadanego udziału albo uzgodnień co do podziału pożytków z rzeczy 35 .

Zarządca, dokonując czynności prawnych i faktycznych dotyczących nieruchomości stanowiącej współwłasność, na gruncie podatku od towarów i usług świadczy usługę zarządu nieruchomością wspólną. Jednakże wynagrodzenia przypadającego zarządcy z tego tytułu nie można zaliczać do podstawy opodatkowania z tytułu świadczenia przez niego, jako jednego ze współwłaścicieli, usługi najmu, ponieważ są to dwie odrębne usługi. Usługa zarządu rzeczą wspólną jest bowiem świadczona na rzecz współwłaścicieli nieruchomości, a nie jej najemcy.

${ }^{33}$ Tak: wyrok NSA z dnia 8 stycznia 2013 r., I FSK 271/12, Legalis nr 759491; wyrok NSA z dnia 19 marca 2014 r., I FSK 579/13, Legalis nr 908692; wyrok NSA z dnia 13 czerwca 2014 r., I FSK 1066/13, Legalis nr 1043110.

${ }^{34}$ Odmiennie, moim zdaniem błędnie, NSA w wyroku z dnia 31 stycznia 2013 r., I FSK 289/12, Legalis nr 759900. Z przedstawionego w uzasadnieniu wyroku stanu faktycznego wynika, że jeden ze współwłaścicieli nieruchomości był współwłaścicielem administrującym i w ramach umowy o administrowanie wynajmował nieruchomość wspólną. Drugi ze współwłaścicieli wystawiał mu fakturę na swoją część czynszu najmu w celu rozliczenia pożytków i na tej podstawie otrzymywał korzyści z tytułu wynajęcia nieruchomości. Sąd błędnie uznał, że podatnikiem z tytułu najmu jest jedynie współwłaściciel administrujący. W uzasadnieniu wyroku Naczelny Sąd Administracyjny wskazał, że „przekazywanie przez jednego ze współwłaścicieli pozostałym współwłaścicielom - odpowiednio do wielkości ich udziałów - pobranych przez niego pożytków z rzeczy jest realizacją uprawnień poszczególnych współwłaścicieli, mających oparcie wprost w przepisach prawa cywilnego. Nie towarzyszy temu żaden wzajemny obowiązek po ich stronie, który by można uznać za świadczenie usługi w rozumieniu VAT-u". Nie można się z tym zgodzić. Należy zaznaczyć, że w uzasadnieniu wyroku Naczelnego Sądu Administracyjnego z dnia 19 marca 2014 r. (I FSK 579/13) skład orzekający w tej sprawie stwierdził, iż nie podziela przedstawionego powyżej stanowiska innego składu orzekającego Naczelnego Sądu Administracyjnego.

${ }^{35}$ Pogląd taki wyraził NSA w wymienionym już wyroku z dnia 13 czerwca 2014 r., I FSK 1066/13. 
Świadczenie należne zarządcy jest zatem wyłącznie ekwiwalentem nakładów w związku z wykonywanymi przezeń czynnościami zarządu i nie może obejmować żadnych innych składników, w tym korzyści z najmu nieruchomości stanowiącej współwłasność. Ciężar wynagrodzenia zarządcy ponoszą zaś współwłaściciele nieruchomości.

Mając na celu potwierdzenie powyższego poglądu, warto odnieść się do orzecznictwa Europejskiego Trybunału Sprawiedliwości dotyczącego podatku od wartości dodanej ${ }^{36}$. W wyroku w sprawie C-427/98 Trybunał wskazał, że niedopuszczalna jest sytuacja, gdy podstawa opodatkowania byłaby wyższa od kwoty, którą podatnik faktycznie otrzymuje ${ }^{37}$. Zatem podstawą opodatkowania z tytułu świadczenia usługi najmu dla zarządcy będzie kwota, którą otrzymuje po podziale, a nie pełna kwota czynszu najmu, jaką otrzymuje od usługobiorcy.

\section{USTANOWIENIE ZARZĄDCY NIEBĘDĄCEGO WSPÓŁWŁAŚCICIELEM A ZAKRES PODMIOTOWY OPODATKOWANIA}

W nawiązaniu do powyższych uwag należy przypomnieć, że osoba trzecia, niebędąca współwłaścicielem, może stać się zarządcą rzeczy wspólnej na mocy umowy współwłaścicieli bądź orzeczenia sądu. Zdarzenie to nie wpływa jednak na zakres podmiotowy opodatkowania podatkiem od towarów i usług wynajęcia nieruchomości wspólnej, skutkując zwiększeniem albo zmniejszeniem liczby podatników.

Jak wcześniej wspomniano, do kompetencji zarządcy należy m.in. zawieranie umów oraz ich wykonywanie. W przypadku umowy najmu, którą zarządca zawiera we własnym imieniu, ale na rzecz współwłaścicieli, najemca płaci czynsz najmu do jego rąk. Następnie należność z tytułu czynszu najmu jest dzielona przez zarządcę na rzecz współwłaścicieli stosownie do postanowień umowy powierzającej mu zarząd rzeczą wspólną, a w przypadku ich braku - w stosunku do wielkości udziałów, zgodnie z art. 207 Kodeksu cywilnego. Przypadające współwłaścicielom korzyści są bowiem zapłatą za świadczoną usługę najmu nieruchomości i w konsekwencji tego są opodatkowane podatkiem od towarów i usług. Każdy z wynajmujących współwłaścicieli jest wówczas podatnikiem czynnym podatku od towarów i usług i w związku z tym powinien wystawić fakturę na swoją część czynszu najmu, przypadającą mu w stosunku do udziału, chyba że współwłaściciele postanowili w umowie o innym sposobie podziału pożytków z rzeczy wspólnej. Podkreślenia wymaga fakt, że w takiej sytuacji zarządca nieruchomości nie jest podatnikiem tego podatku z tytułu wynajęcia nieruchomości

${ }^{36}$ Zob. dyrektywa Rady 2006/112/WE z dnia 28 listopada 2006 r. w sprawie wspólnego systemu podatku od wartości dodanej (Dz.Urz. UE. L nr 347, s. 1 ze zm.).

${ }^{37}$ Zob. wyrok ETS z dnia 15 października 2002 r., C-427/98, Legalis nr 153353. 
wspólnej. Przekazuje on jedynie korzyści należne współwłaścicielom, którzy faktycznie są wynajmującymi, a sam z tytułu najmu nic nie uzyskuje.

Zarządca, będący podatnikiem w rozumieniu art. 15 ustawy o podatku od towarów i usług, dokonując czynności zarządu rzeczą wspólną, świadczy na rzecz współwłaścicieli usługę zarządu. W zamian za nią, na podstawie art. 205 Kodeksu cywilnego, otrzymuje stosowne wynagrodzenie, które podlega opodatkowaniu podatkiem od towarów i usług. Stanowi ono zapłatę za świadczoną na rzecz współwłaścicieli usługę zarządu, której jednym z elementów jest zawieranie umów najmu na rzecz współwłaścicieli. Jak trafnie stwierdził Naczelny Sąd Administracyjny, „czynności najmu wykonywanych w ramach zarządu nie można odrywać od czynności samego zarządu, najem nieruchomości bowiem odbywa się w ramach czynności zarządu" ${ }^{38}$. Świadczenie należne zarządcy w zamian za sprawowanie zarządu jest co do zasady wyłącznie ekwiwalentem dokonanych nakładów poczynionych w związku z wykonywaniem zarządu, nie wchodzi natomiast do niego należność z tytułu czynszu najmu. Podstawą opodatkowania dla zarządcy jest wyłącznie wynagrodzenie za świadczoną usługę najmu. Kwota należna obejmuje jedynie wynagrodzenie za usługę zarządu i nie może być powiększona o żadne dodatkowe składniki, w szczególności o kwoty wpłat dokonywanych przez najemców lokali, gdyż do takiego zabiegu brak jest odpowiedniej podstawy prawnej ${ }^{39}$. W takim przypadku beneficjentami umów najmu są wyłącznie współwłaściciele nieruchomości i to oni są podatnikami czynnymi podatku od towarów i usług w związku z jej wynajęciem, a nie zarządca, na którym ciąży obowiązek podatkowy tylko z tytułu świadczonej usługi zarządu.

$\mathrm{Na}$ zakończenie uwag dotyczących zarządcy będącego osobą trzecią warto zwrócić uwagę na pogląd wyrażony przez Naczelny Sąd Administracyjny w jednym z wyroków:

[...] za słuszną należy uznać tezę, że tylko zapłata podatku przez podatnika prowadzi do realizacji zobowiązania podatkowego i tym samym do jego wygaśnięcia. Sytuacji tej nie zmieniałaby nawet okoliczność, że zarządca płaciłby podatek VAT nie w swoim imieniu, lecz w imieniu skarżącej. Płacenie podatków jest bowiem osobistą powinnością każdego podatnika, która nie może być przerzucana mocą umów cywilnoprawnych na inne podmioty, na co zresztą zwracały uwagę stronie organy podatkowe $\mathrm{w}$ toku prowadzonego postępowania ${ }^{40}$.

Wobec powyższego trzeba podkreślić, że prawidłowe opodatkowanie usługi najmu nieruchomości stanowiącej współwłasność zachodzi tylko wtedy, gdy pod-

${ }^{38}$ Tak: wyrok NSA z dnia 2 kwietnia 2012 r., I FSK 820/11, Legalis nr 491627.

${ }^{39}$ Zob. wyrok NSA z dnia 28 czerwca 2012 r., I FSK 1538/11, Legalis nr 779334.

${ }^{40}$ Tak: wyrok NSA z dnia 8 stycznia 2013 r., I FSK 271/12, Legalis nr 759491. Więcej na temat obchodzenia prawa podatkowego za pomocą umów cywilnoprawnych zob. A. Hanusz, op. cit., s. $42-43$. 
miot, który odniósł korzyść z tej usługi osobiście, zapłaci podatek. Z całą pewnością umowa cywilnoprawna z zarządcą nie może tej powinności znieść.

\section{PODSUMOWANIE}

Reasumując, należy stwierdzić, że prawidłowe ustalenie czynnych podatników podatku od towarów i usług z tytułu usługi najmu nieruchomości stanowiącej współwłasność jest uzależnione od wskazania współwłaścicieli, którzy faktycznie otrzymują korzyść ze świadczonej usługi. Aby osiągnąć taki stan rzeczy, organy podatkowe winny ustalić stan faktyczny z należytym zastosowaniem przepisów prawa cywilnego dotyczących współwłasności rzeczy. Sięgnięcie do odpowiednich przepisów prawa cywilnego jest niezbędne, gdyż ustawa o podatku od towarów i usług nie definiuje w sposób odrębny od regulacji cywilnoprawnych pojęć charakterystycznych dla współwłasności rzeczy.

Pierwsze $\mathrm{z}$ wymienionych zdarzeń cywilnoprawnych, czyli podział quoad usum nieruchomości, będzie co do zasady wpływało na krąg podatników czynnych podatku od towarów i usług z tytułu usługi najmu nieruchomości wspólnej. Część nieruchomości, jaką współwłaściciel otrzymał do wyłącznego korzystania, może zostać wynajęta i wskutek tego będzie on jedynym czynnym podatnikiem tego podatku. Nie będą nimi pozostali współwłaściciele nieruchomości, ponieważ umowa najmu odnosi się do części nieruchomości wspólnej i w ten sposób nie przysparza im żadnych korzyści.

Ustanowienie zarządcy nieruchomości wspólnej, zarówno z grona współwłaścicieli, jak i osoby niebędącej współwłaścicielem, nie wpływa na zakres podmiotowy opodatkowania wynajęcia nieruchomości wspólnej. W sytuacji ustanowienia zarządcy będącego współwłaścicielem podatnikami czynnymi podatku od towarów i usług z tytułu wynajęcia wspólnej nieruchomości są wszyscy współwłaściciele, gdyż to oni otrzymują korzyści ze świadczonej usługi. Z kolei w przypadku, gdy zostanie ustanowiony zarządca niebędący współwłaścicielem, podatnikami w przedmiotowej sytuacji będą współwłaściciele, a nie zarządca.

Ustawa o podatku od towarów i usług często posługuje się pojęciami ukształtowanymi w prawie cywilnym i jednocześnie nie nadaje im swoistego znaczenia w definicji ustawowej ani nie odsyła do odpowiednich regulacji prawa cywilnego. W takiej sytuacji, mając na uwadze zasadę jedności systemu prawa, powinno się ustalać podatkowe stany faktyczne $\mathrm{w}$ zgodzie $\mathrm{z}$ terminologią przyjętą $\mathrm{w}$ prawie cywilnym i zasadami regulującymi daną instytucję prawa cywilnego. Niestety, praktyka stosowania prawa pokazuje, że nieczęsto ma to miejsce. 


\section{BIBLIOGRAFIA}

Brzeszczyńska S., Wynajęcie nieruchomości wspólnej przez skłóconych wspótwłaścicieli, „Nieruchomości” 2015, nr 9.

Cisek A., Górska K., [w:] Kodeks cywilny. Komentarz, red. E. Gniewek, P. Machnikowski, Warszawa 2013.

Czerwińska-Koral K., Podział quoad usum nieruchomości rolnej, Warszawa 2015.

Durzyńska M., Podziat nieruchomości, Warszawa 2011.

Dyrektywa Rady 2006/112/WE z dnia 28 listopada 2006 r. w sprawie wspólnego systemu podatku od wartości dodanej (Dz.Urz. UE. L nr 347, s. 1 ze zm.).

Gniewek E., [w:] System Prawa Prywatnego, t. 3: Prawo rzeczowe, red. E. Gniewek, Warszawa 2013.

Hanusz A., Zasada autonomii woli stron stosunków cywilnoprawnych w świetle prawa podatkowego, „Państwo i Prawo” 1998, z. 12.

Ignatowicz J., [w:] Kodeks cywilny. Komentarz, red. J. Ignatowicz, J. Pietrzykowski, t. 1, Warszawa 1972.

Interpretacja indywidualna Dyrektora Izby Skarbowej w Warszawie z dnia 30 marca 2009 r., IPPP1/443-91/09-4/AW.

Krywan T., VAT. Komentarz 2013, Wrocław 2013.

Kunicki A., [w:] System Prawa Cywilnego, t. 2: Prawo własności i inne prawa rzeczowe, red. W. Czachórski, Warszawa 1977.

Matusiakiewicz Ł., Najem nieruchomości a VAT - kontrowersyjne problemy w świetle najnowszych interpretacji organów podatkowych, „Nieruchomości” 2012, $\mathrm{nr} 4$.

Michalik T., VAT. Komentarz, Warszawa 2015.

Orzeczenie SN z dnia 13 kwietnia 1966 r., II CR 24/66, „Państwo i Prawo” 1968, z. 2.

Orzeczenie SN z dnia 26 kwietnia 1966 r., I CR 712/63, OSN 1966, poz. 221.

Rudnicki S., Rudnicki G., Rudnicka J., [w:] Kodeks cywilny. Komentarz, Księga II: Własność i inne prawa rzeczowe, red. J. Gudowski, Warszawa 2013.

Skowrońska-Bocian E., [w:] Kodeks cywilny. Komentarz, red. K. Pietrzykowski, t. 1, Warszawa 2011.

Szczęśniak P., Glosa do wyroku Naczelnego Sądu Administracyjnego z dnia 5 lutego 2015 r., sygn. akt II FSK 146/13 (dot. nieskuteczności umowy o podział quoad usum na gruncie ustawy o podatku od spadków i darowizn), ,Zeszyty Naukowe Sądownictwa Administracyjnego” 2015, z. 6.

Uchwała SN z dnia 8 stycznia 1980 r., III CZP 80/79, Legalis nr 21842.

Ustawa z dnia 23 kwietnia 1964 r. - Kodeks cywilny (t.j. Dz.U. z 2016 r., poz. 380 ze zm.).

Ustawa z dnia 17 listopada 1964 r. - Kodeks postępowania cywilnego (t.j. Dz.U. z 2014 r., poz. 101 ze zm.).

Ustawa z dnia 11 marca 2004 r. o podatku od towarów i usług (t.j. Dz.U. z 2016 r., poz. 710 ze zm.).

Winiarz J., [w:] Kodeks cywilny z komentarzem, red. J. Winiarz, t. 1, Warszawa 1989.

Wolter A., Prawo cywilne. Zarys części ogólnej, Warszawa 1979.

Wyrok ETS z dnia 15 października 2002 r., C-427/98, Legalis nr 153353.

Wyrok NSA z dnia 2 kwietnia 2012 r., I FSK 820/11, Legalis nr 491627.

Wyrok NSA z dnia 28 czerwca 2012 r., I FSK 1538/11, Legalis nr 779334.

Wyrok NSA z dnia 8 stycznia 2013 r., I FSK 271/12, Legalis nr 759491.

Wyrok NSA z dnia 31 stycznia 2013 r., I FSK 289/12, Legalis nr 759900.

Wyrok NSA z dnia 19 marca 2014 r., I FSK 579/13, Legalis nr 908692.

Wyrok NSA z dnia 13 czerwca 2014 r., I FSK 1066/13, Legalis nr 1043110. 
Wyrok NSA z dnia 25 sierpnia 2015 r., I FSK 1672/13, Legalis nr 1361710.

Wyrok NSA z dnia 1 października 2015 r., I FSK 1004/13, Legalis nr 1362239.

Wyrok SA w Gdańsku z dnia 15 czerwca 1993 r., I ACr 400/93, Legalis nr 46319.

Wyrok SN z dnia 29 grudnia 1967 r., III CRN 306/67, OSNCP 1968, poz. 215.

Wyrok SN z dnia 10 lutego 2004 r., IV CK 17/03, Legalis nr 68861.

\section{SUMMARY}

This elaboration is concentrated on the influence of certain civil law actions referring to the relationship between co-owners on the subjective scope of the taxation with tax on goods and services of leasing the property constituting the co-ownership. One should notice that numerous and divergent judicial decisions are attesting to the importance of this problem. In the article there were described certain civil law actions referring to the co-ownership of property, so as the quoad usum division of property, establishing the administrator of property, which is a co-owner and establishing the administrator, which is not a co-owner. Next, there was made an analysis of the influence of these actions on the subjective scope of taxing the service of leasing the property constituting the co-ownership. It must be emphasized that those matters concern also another problem, to wit, links of tax law with the civil law.

Keywords: property; co-ownership; quoad usum division; administrator; lease; tax on goods and services; service; taxpayer 